\title{
日本脳神経外科コングレス 会員各位殿
}

\author{
企画・監修 日本脳神経外科学会 \\ 日本脳神経外科コングレス \\ VIDEO JOURNAL of Japan Neurosurgery \\ 編集委員会 佐野圭司、石井昌三、 \\ 高倉公朋、田中隆一、 \\ 山浦 晶、児玉南海雄、 \\ 桐野高明、橋本信夫
}

\section{「VIDEO JOURNAL of Japan Neurosurgery」新年度会員募集のお知らせ}

日本脳神経外科学会・日本脳神経外科コングレスでは、1993年1月より学会事業の 一環として「VIDEO JOURNAL of Japan Neurosurgery」を年4 回発刊しています。

このVIDEO JOURNALは、学会会員の卒後・生涯教育を主目的として、学会が主 体となって発刊するものです。

ビデオの内容は、編集委員会で指定編集したテーマと、会員からの投稿ビデオに よって構成されており、たいへんバラエティーに富んだものです。またビデオケース に同封されております学会事務局あての葉書を提出しますと、専門医資格維持のため の単位がビデオ 1 本につき 2 単位、年間 8 単位まで取得できます。

発刊運営方法は、ビデオの市販は一切行わず、ビデオ会員からの会費によって運営 されています。日本脳神経外科コングレスの皆様が、VIDEO JOURNAL of Japan Neurosurgeryを積極的に活用されますようご案内申し上げます。

なお、ビデオの製作・頒布業務は株式会社メディカルリサーチセンターに委託して いますので、下記要領をご参照の上、お申し込下さい。

記

名 称 VIDEO JOURNAL of Japan Neurosurgery

発刊月 毎年1月、4月、7月、10月の 4 回発刊。

・ビデオの長さ 60 分

○価格 (1)年 4 回発刊分を一括申込の場合は、31,500円（消費税、送料込）

(2)個別申込の場合は、1本8,400円（消費税、送料込）

申申 込 方 法 (1)申込葉書の投函と同時に、下記指定口座に所定の金額をお振り込 下さい。

神田信用金庫 飯田橋支店 普通預金 0164421

日本脳神経外科ビデオジャーナルロ

(2)個別申込の場合は、必要発刊月を記入し、お申し込下さい。

(3)振込手数料は、各自でご負担下さい。

業務委託先 テ101-0061 東京都千代田区三崎町3-10-15 富士ビル 3 階

株式会社メディカルリサーチセンター

VIDEO JOURNAL of Japan Neurosurgery 係

電話 03-3263-1827 FAX 03-3263-1829 